\title{
EFFECT OF CYANOBACTERIA Nostoc calcicola ON ANTIOXIDANT SYSTEM OF SOYBEAN
}

\author{
Mai Van Chung ${ }^{1, *}$, Mai Thi Thanh Huyen², Dinh Thi Truong Giang ${ }^{2}$ \\ ${ }^{I}$ Faculty of Biology, Vinh University, 182 Le Duan str., Vinh city, Nghe An province \\ ${ }^{2}$ Faculty of Chemistry, Vinh University, 182 Le Duan str., Vinh city, Nghe An province \\ *Email: chungmv@vinhuni.edu.vn
}

Received: 2 June 2015; Accepted for publication: 24 September 2015

\begin{abstract}
Strain Nostoc calcicola HN9 of Cyanobacteria, which was in the static culture, was collected biomass in death and $\log$ phases to exam its effect on the antioxidant system of soybean [Glycine $\max$ (L.) Merr. "Nam Dan"] in the vegetative stages.

Suspension of $N$. calcicola HN9 in death phase caused to oxidative stress in soybean leaves with a burst of superoxide anion radical $\left(\mathrm{O}_{2}{ }^{-}\right)$in stage $\mathrm{V} 1$ and hydrogen peroxide $\left(\mathrm{H}_{2} \mathrm{O}_{2}\right)$ in stage V3. In N. calcicola HN9-treated plants, whereas generation of ascorbic acid was inhibited, total phenolics was early accumulated to high content; parallel, activity of enzymes such as superoxide dismutases (SOD), catalase (CAT), ascorbate peroxidases (APX) and polyphenol oxidase (PPO) were enhanced during the vegetative stages. An enhancement of SOD, CAT, and APX firmly regulated ROS products to reduce cellular damages, and allowed them to play crucial function in enhancement soybean tolerance, whereas, the defensive role of PPO should be more clarified in the prospective studies.

Contrary, suspension of N. calcicola HN9 in log phase only raised content of ascorbic acid, and induced activity of SOD and APX, however, its accumulated level was lower than that in death phase. Lack of convinced evidences discribed how strain N. calcicola HN9 in log phase affected to biosynthesis of total phenolics and activity of CAT and PPO.
\end{abstract}

Keywords: soybean "Nam Dan", cyanobacteria, Nostoc calcicola HN9, enzymatic antioxidant; non-enzymatic antioxidant.

\section{INTRODUCTION}

Generation of reactive oxygen species (ROS), including hydrogen peroxide $\left(\mathrm{H}_{2} \mathrm{O}_{2}\right)$ and superoxide anion radical $\left(\mathrm{O}_{2}{ }^{-}\right)$, is a common phenomenon in plants [1]. The accumulation of these ROS often connect to plant defense responses, which might be a central component mediating cross-tolerance [2]. However, ROS can exert toxic effects, and their uncontrolled levels can result in oxidative damage of cellular components, change the membrane ion fluxes, and often associate loss of function leading to cell death [3]. Plants protect themselves to stresses 
through different defense mechanisms, in which, the change in property of non-enzymatic and enzymatic components of the antioxidant system has been suggested to be among first responses [4]. The typical non-enzymatic components comprise of ascorbic acid (vitamin C), total phenolics, and common enzymatic components include superoxide dismutases (SOD, EC 1.15.1.1), catalase (CAT, EC 1.11.1.6), ascorbate peroxidases (APX, EC 1.11.1.11) and polyphenol oxidase (PPO, EC 1.10.3.2). These antioxidants operate in different subcellular mechanisms and respond in concert when cells are exposed to oxidative stress via controlling biosynthesis of $\mathrm{H}_{2} \mathrm{O}_{2}$ and $\mathrm{O}_{2}{ }^{-}$, maintain ROS in low level [5], therefore, reduce oxidative damage.

Cyanobacteria have been known to produce a great number of bioactive compounds such as phytohormones, enzymes, antibacterial and antiviral substances, etc... that improve plant growth and productivity as well as stimulate plant defense system [6]. Several cyanobacteria species have been applied to improve quality of agricultural production. In four-phase static culture of cyanobacteria, suspension collected in log phase or stationary phase expresses positive effects to crops. In the death phase (decline phase), suspension often contains several decomposing productions such as ethanol, organic acids... that are toxic to plants. Suspension in death phase plays as unfavourable factor that cause damage to plants and lead to operate defense mechanism.

The main objective of this work was to find out the different influences of Nostoc calcicola HN9 collected in log phase and/or death phase on the antioxidant system of Glycine max (L.) Merr. "Nam Dan" - a local cultivar of soybean associated with the famous product as "Nam Dan sauce". This cultivar was degenerated and has just been regenerated since the year of 2009; its physiological, biochemical characteristics need to be specifically fulfilled.

\section{MATERIALS AND METHODS}

\subsection{Materials}

Plant used in experiments is cultivar "Nam Dan" of soybean [Glycine max (L.) Merr.]. Soybean seeds have been provided by Nam Dan Centre of Agricultural Extension.

Strain Nostoc calcicola HN9 is isolated and cultured in the Phycology labs, Vinh University.

\subsection{Experiment}

\subsubsection{Preparing the cyanobacterial suspension}

Strain N.calcicola HN9 is homogeneously cultured in BG11 medium. Biomass was collected in log phase and death phase, centrifuged twice at $10.000 \times \mathrm{g}$ for 15 minutes to remove culture medium, and then diluted in distilled water into the tested suspensions with separately concentrations such as $0.10,0.30$ and 0.50 gram per litre $(\mathrm{g} / \mathrm{L})$.

\subsubsection{Setting up experimental formulae}

Soybean seeds were surface-sterilized by $\mathrm{HgCl}_{2} 0.01 \%$ and incubated in $22-23{ }^{\circ} \mathrm{C}$. After imbibing in Petri dishes 48 hours, germinating seeds were put in neutral plastic boxes containing 
Hoagland medium. Experiments were carried out in the growth chamber (Department of Plant Physiology, Vinh University) at temperature of $25-27{ }^{\circ} \mathrm{C}$, relative humidity of $65-70 \%$, irradiance of $110-130 \mu \mathrm{mol} . \mathrm{m}^{-2} \cdot \mathrm{s}^{-1}$ and light regime of $14 \mathrm{~h} \mathrm{light} / 10 \mathrm{~h}$ dark.

In the $10^{\text {th }}$ day after emergence out of ground, surface of soybean leaves were sprayed by the cyanobacterial suspension following formulae $(\mathrm{F})$ such as:

+ F1: plants treated by suspension of strain N.calcicola HN9 in death phase, concentration of $0.10 \mathrm{~g} / \mathrm{L}$;

+ F2: plants treated by suspension of strain N.calcicola HN9 in death phase, concentration of $0.30 \mathrm{~g} / \mathrm{L}$;

+ F3: plants treated by suspension of strain N.calcicola HN9 in death phase, concentration of $0.50 \mathrm{~g} / \mathrm{L}$;

+ F4: plants treated by suspension of strain N.calcicola HN9 in log phase, concentration of $0.10 \mathrm{~g} / \mathrm{L}$;

+ F5: plants treated by suspension of strain N.calcicola HN9 in log phase, concentration of $0.30 \mathrm{~g} / \mathrm{L}$; $0.50 \mathrm{~g} / \mathrm{L}$.

+ F6: plants treated by suspension of strain N.calcicola HN9 in log phase, concentration of

Formula control is without cyanobacteria treatment.

Leaves in control and treated plants were carefully collected in specific time as (1) before treating by cyanobacterial suspension, (2) seedlings in stage V1 with one unrolled trifoliolate leaf, (3) plants in stage V3 with two unrolled trifoliolates enclosing auxillary buds and (4) plants in stage V5 with 5 unrolled trifoliates. Leaves were weighed, frozen in liquid nitrogen and kept at $-80{ }^{\circ} \mathrm{C}$ for subsequent analyses of antioxidant enzymes and compounds. Content of hydrogen peroxide $\left(\mathrm{H}_{2} \mathrm{O}_{2}\right)$ and superoxide anion radical $\left(\mathrm{O}_{2}{ }^{-}\right)$was determined in fresh materials at particular time points for all variants.

\subsection{Methods of analysis}

\subsubsection{Chemicals and equipment}

All chemicals used for analysis were purchased from Sigma-Aldrich (USA).

Analyses were carried out on the Agilent Cary 60 UV-Vis Spectrophotometer (USA) connected with computer. Data were processed by the Cary WinUV software version 5.0.

\subsubsection{Determination of hydrogen peroxide and superoxide anion radical content}

Content of hydrogen peroxide $\left(\mathrm{H}_{2} \mathrm{O}_{2}\right)$ was determined following the spectrophotometric method described by Becana et al. (1986) [7]. The amount of $\mathrm{H}_{2} \mathrm{O}_{2}$ in soybean leaves was expressed as $\mu \mathrm{mol} . \mathrm{g}^{-1} \mathrm{FW}$.

Determination of superoxide anion radical $\left(\mathrm{O}_{2}{ }^{\circ}\right)$ content was based on its ability to reduce nitro blue tetrazolium (Doke, 1983) [8]. Level of $\mathrm{O}_{2}{ }^{-}$in soybean leaves was expressed as absorbance at $580 \mathrm{~nm}$ per $1 \mathrm{~g}$ fresh materials $\left(\mathrm{A}_{580} \cdot \mathrm{g}^{-1} \mathrm{FW}\right)$. 


\subsubsection{Quantification of non-enzymatic antioxidants}

Ascorbic acid and total phenols were analyzed by methods of Kampfenkel et al. [9] and Mechikova et al.[10], respectively. Content of these non-enzymatic antioxidants were expressed as miligram/gram fresh materials $\left(\mathrm{mg} \cdot \mathrm{g}^{-1} \mathrm{FW}\right)$.

\subsubsection{Assays of enzymatic antioxidants}

Enzymes in soybean leaves were extracted by homogenizing with an identified volume of phosphate buffer ( $\mathrm{pH} 7.0)$. After that, the homogenate was centrifuged at $12.000 \times \mathrm{g}$ for 20 minutes at $4{ }^{\circ} \mathrm{C}$. The supernatant was selected for enzyme assays.

Activity of superoxide dismutases (SOD) was measured according to modification from method of Scebba et al. [11]. Catalase (CAT) activity was assayed following the method of Chen et al. [12] with minor modification. Ascorbate peroxidases (APX) activity was analyzed following the method of Cao et al. [13]. Polyphenol oxidase (PPO) activity was measured by the method of González et al. [14]. Enzymatic unit was expressed as nanokatal per miligram protein (nkat.mg ${ }^{-1}$ protein).

Protein concentrations in extracts were quantified by Bradford's method with bovine albumin as the standard [15].

\subsubsection{Statistical analysis}

All analyses were performed in at least three replicates in three independent experiments. Analysis of variance (ANOVA) was applied to verify whether means from independent experiments within a given experimental variant were significant with level of significance $\alpha=0.05$. Data shown in the figures are means and standard errors (s.e.) for each variant.

\section{RESULTS AND DISCUSSION}

\subsection{Effect of cyanobacterial suspension on hydrogen peroxide and superoxide anion radical in "Nam Dan" soybean leaves}

Suspension of N.calcicola HN9 induced to release ROS such as hydrogen peroxide $\left(\mathrm{H}_{2} \mathrm{O}_{2}\right)$ and superoxide anion radical $\left(\mathrm{O}_{2}{ }^{-}\right)$in "Nam Dan" soybean leaves (Fig. 1). Generation and alteration of $\mathrm{H}_{2} \mathrm{O}_{2}$ and $\mathrm{O}_{2}{ }^{-}$are different from effects of N.calcicola $\mathrm{HN} 9$ in death phase and log phase, howerer, content of these ROS in all cyanobacteria-treated formulae is significant higher than in controls, which maintained in low levels during the vegetative stages of soybean.

Treatment by different suspensions induced to differently generate of $\mathrm{H}_{2} \mathrm{O}_{2}$ in "Nam Dan" soybean leaves (Fig. 1a). Strain N.calcicola HN9 in death phase induced this ROS molecule rapidly increase to peak in stage $\mathrm{V} 3$, in which intensity of $\mathrm{H}_{2} \mathrm{O}_{2}$ generated correlating with effects of cyanobacteria concentration. Maximum $\mathrm{H}_{2} \mathrm{O}_{2}$ content $\left(9.16 \mu \mathrm{mol} . \mathrm{g}^{-1} \mathrm{FW}\right)$ was accumulated in the highest concentration $(0.50 \mathrm{~g} / \mathrm{L})$ formula, having by 2.48 -fold higher than in control $\left(3.69 \mu \mathrm{mol} . \mathrm{g}^{-1} \mathrm{FW}\right)$. After that, generation of $\mathrm{H}_{2} \mathrm{O}_{2}$ strong reduced in stage V5. Contrary, content of $\mathrm{H}_{2} \mathrm{O}_{2}$ in leaves treated by strain N.calcicola $\mathrm{HN} 9$ in $\log$ phase slightly increased during the vegetative stages of soybean. 


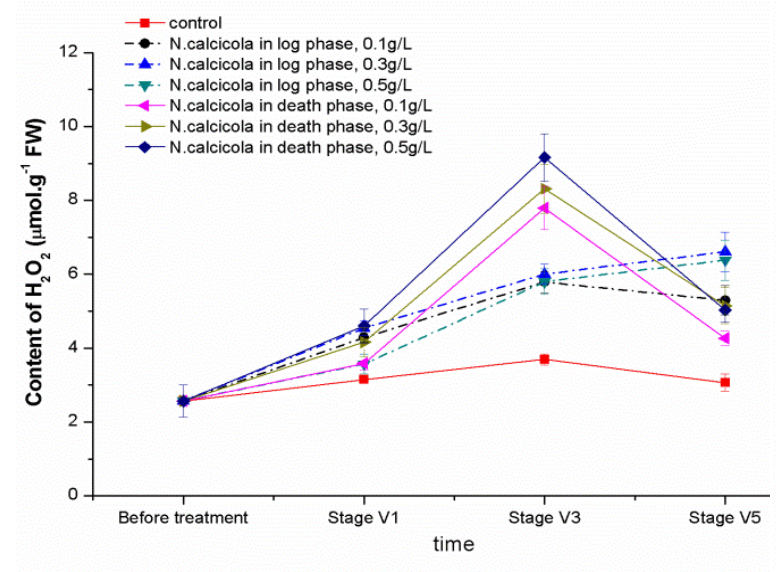

a

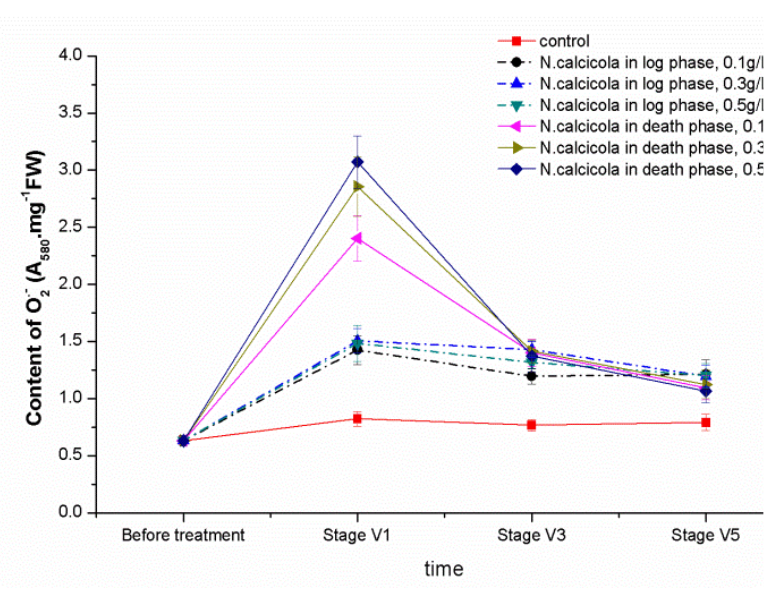

$\mathrm{b}$

Figure 1. Effect of N. calcicola suspension on hydrogen peroxide (a) and superoxide anion radical (b) in "Nam Dan" soybean leaves.

Similar to $\mathrm{H}_{2} \mathrm{O}_{2}$ generation, release of $\mathrm{O}_{2}{ }^{--}$was strongly induced after treatment by strain N.calcicola $\mathrm{HN} 9$ in death phase but reached to peak earlier in the stage $\mathrm{V} 1$, where content of $\mathrm{O}_{2}{ }^{*}$ was recorded to correlate with influence of cyanobacteria concentrations (Fig. 1b). Following a significant reduction from stage $\mathrm{V} 1$ to stage $\mathrm{V} 3, \mathrm{O}_{2}{ }^{-}$in $N$. calcicola -treated leaves maintained in low level till ending of experiment. Comparing with effect of strain N.calcicola HN9 in death phase, release of $\mathrm{O}_{2}^{-}$in formulae treated by strain $\mathrm{HN} 9$ in log phase was similar to; however, value of peak was much lower. The highest content of $\mathrm{O}_{2}{ }^{-}$generated in leaves treated by $0.3 \mathrm{~g} / \mathrm{L}$ concentration $\left(1.503 \mathrm{~A}_{580} \cdot \mathrm{g}^{-1} \mathrm{FW}\right)$ only corresponded to $48.94 \%$, compared to that in plants treated by strain N.calcicola HN9 in death phase $\left(3.071 \mathrm{~A}_{580} \cdot \mathrm{g}^{-1} \mathrm{FW}\right)$.

A strong generation of ROS level together with induction cell death in damaged area is the oxidative response in plant defense against stresses [3]. Our recent study on "Nam Dan" soybean-lead $(\mathrm{Pb})$ interaction [16] discovered that, an enhancement of $\mathrm{H}_{2} \mathrm{O}_{2}$ và $\mathrm{O}_{2}{ }^{-}$improved the self-defense capability of soybean, of which, signalling molecule $\mathrm{H}_{2} \mathrm{O}_{2}$ triggered defense cascades, and $\mathrm{O}_{2}{ }^{-}$is an improtant component in that mechanism [2]. Containing toxic subtances, $N$. calcicola $\mathrm{HN} 9$ in death phase played as unfavourable factor that resulted in oxidative stress to "Nam Dan" soybean and also induced plant defenses concerning accumulation of $\mathrm{H}_{2} \mathrm{O}_{2}$ and $\mathrm{O}_{2}{ }^{\circ}$.

\subsection{Effect of cyanobacterial suspension on non-enzymatic antioxidants in "Nam Dan" soybean leaves}

N. calcicola HN9 suspensions differently effected on metabolism of ascorbic acid and total phenolics in "Nam Dan" soybean leaves, whereas, these non-enzymatic antioxidants in control plants were in minor changes from beginning to ending of experiments (Fig. 2).

Suspension of N.calcicola HN9 in death phase seems to inhibit the biosynthesis of ascorbic acid as content of that antioxidant in cyanobacteria-treated soybean leaves was lower than in control. Contrary, N. calcicola HN9 in log phase induced this process. Ascorbic acid in cyanobacteria-treated leaves rapidly increased to high level in stage V1 $\left(3.49-3.77 \mathrm{mg}^{-1} \mathrm{~g}^{-1} \mathrm{FW}\right)$. After the peak point, ascorbic acid slightly reduced to stage V5, however, its content was always significant higher than in control. Concentration of $0.30 \mathrm{~g} / \mathrm{L}$ showed the best positive effect as 
content of ascorbic acid in soybean leaves influenced by this concentration was the highest in all point of studied time (Fig. 2a).

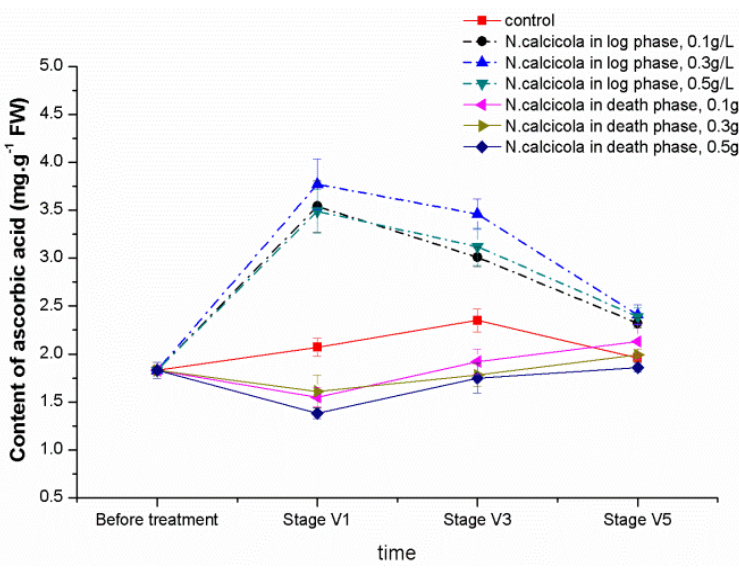

a

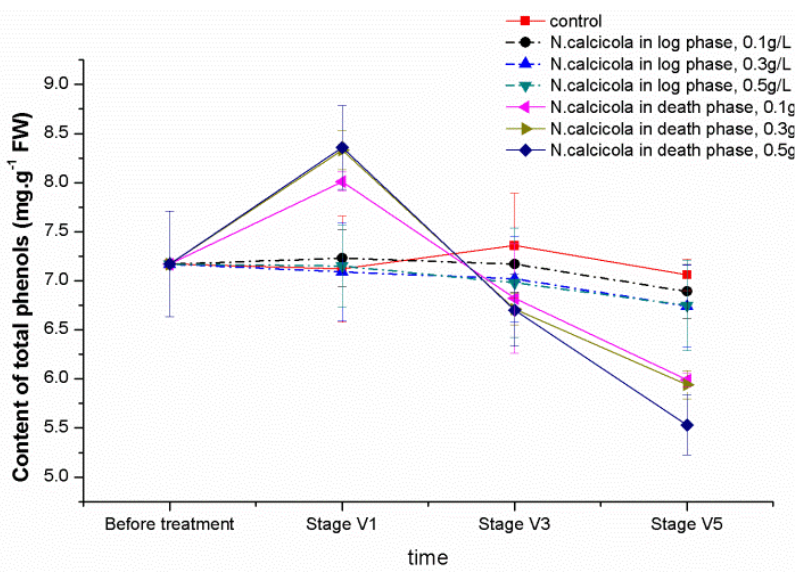

b

Figure 2. Effect of N. calcicola suspension on ascorbic acid (a) and total phenolics in "Nam Dan" soybean leaves.

Different from ascorbic acid, total phenolics in soybean leaves treated by N.calcicola HN9 in log phase and in control plants was similar in a certain level (Fig. 2b). N.calcicola HN9 in death phase caused a big fluctuation in content of total phenolics. A large amount of these antioxidative subtances was early released and reached to peak in stage V1 by the highest content $\left(8.01-8.36 \mathrm{mg} \cdot \mathrm{g}^{-1} \mathrm{FW}\right)$ in $0.50 \mathrm{~g} / \mathrm{L}-$ treated soybean, which is $12.50-17.41 \%$ higher than in control $\left(7.12 \mathrm{mg} \cdot \mathrm{g}^{-1} \mathrm{FW}\right)$. In next growth stages, total phenolics rapidly decreased to level that was significant lower than in control. ANOVA firmly recorded a correlation between content of total phenolics and concentration of strain N.calcicola HN9 in death phase.

\subsection{Effect of cyanobacterial suspension on antioxidant enzymes in "Nam Dan" soybean leaves}

\subsubsection{Activity of CAT}

Activity of CAT in leaves treated by $N$. calcicola HN9 suspension in log phase was in a minor alteration (17.49 - 21.29 nkat. $\mathrm{mg}^{-1}$ protein) during the vegetative stages of "Nam Dan" soybean, and was similar to expression of this enzym in control (18.33 - 21.41 nkat.mg $^{-1}$ protein). Contrary, CAT activity in the treatment formulae of N.calcicola HN9 in death phase was continuously increased and was proportional to effect from the used concentrations. The highest activity of CAT obtained in $0.5 \mathrm{~g} / \mathrm{L}$-treated soybean in stage V5 was $36.75 \mathrm{nkat}^{\mathrm{mg}} \mathrm{m}^{-1}$ protein, having by 1.72-fold and 2.01-fold higher than in control and at beginning, respectively (Fig. 3).

Functioning to catalyze $\mathrm{H}_{2} \mathrm{O}_{2}$ into $\mathrm{H}_{2} \mathrm{O}$ and $\mathrm{O}_{2}$, a strong enhancement of CAT in soybean leaves treated by $N$. calcicola $\mathrm{HN} 9$ in death phase decreased level of $\mathrm{H}_{2} \mathrm{O}_{2}$ since stage V3 (Fig. 1a), therefore, protects the cells against an excess of $\mathrm{H}_{2} \mathrm{O}_{2}$ and thus against considerable membrane damage. 


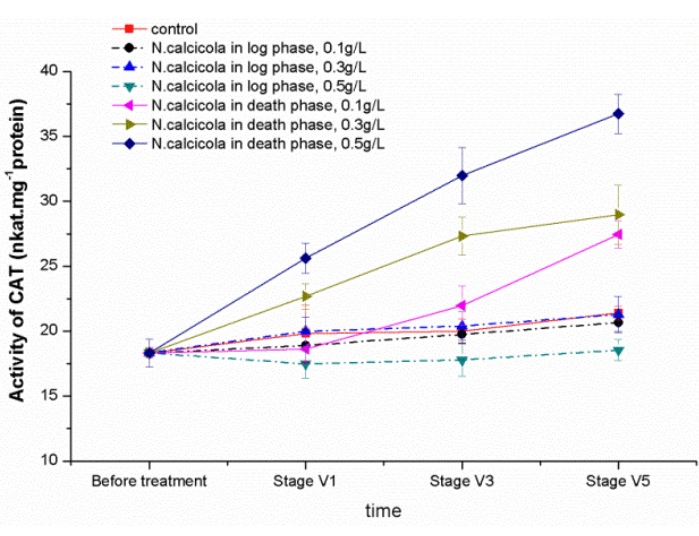

Figure 3. Effect of $N$. calcicola suspension on activity of enzyme enzyme catalase (CAT) in "Nam Dan" soybean leaves.

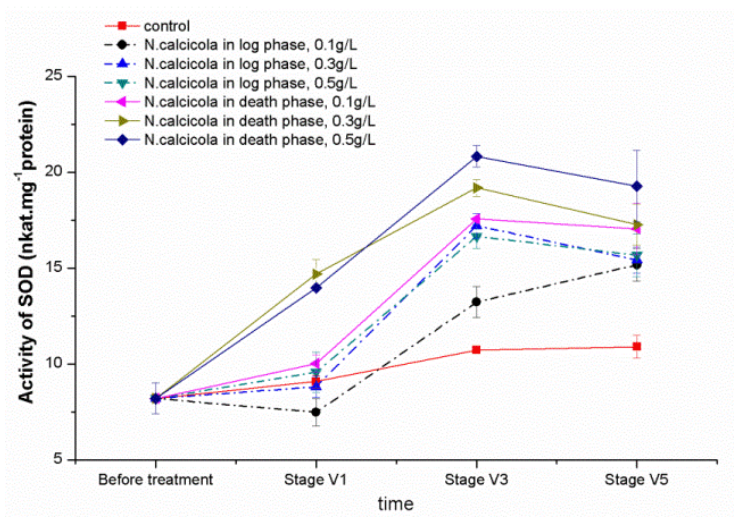

Figure 4. Effect of $N$. calcicola suspension on activity of enzyme superoxide dismutases (SOD) in "Nam Dan" soybean leaves.

\subsubsection{Activity of $S O D$}

Analyses of spectrophotometric assays showed that, activity of SOD in control litte

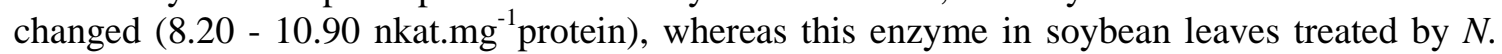
calcicola $\mathrm{HN} 9$ in different phases expressed a big fluctuation in studied time (Fig. 4).

Being induced earlier and stronger than others, SOD activity in formulae of N.calcicola HN9 in death phase increased rapidly, reached to maximum levels as soybean in stage V3. The highest activity of SOD recorded in $0.5 \mathrm{~g} / \mathrm{L}$-treated leaves was 20.83 nkat. $\mathrm{mg}^{-1}$ protein, having by 1.94-fold and 2.54-fold higher than that in control (10.72 nkat. $\mathrm{mg}^{-1}$ protein) and before treating by N.calcicola HN9 (8.20 nkat. $\mathrm{mg}^{-1}$ protein). In addition, SOD activity in leaves treated by HN9 in death phase was always higher than control and formulae of N.calcicola HN9 in log phase. ANOVA results surely confirmed a correlation between activity of SOD and concentration of $N$. calcicola $\mathrm{HN} 9$ when soybean was in stages of V3 and V5.

Activity of SOD in leaves treated by N.calcicola HN9 in log phase showed the similar trend of changing, however, was lower level in comparing to that in death phase. After a minor alteration from beginning to stage V1, SOD activity in soybean leaves treated by concentrations of 0.30 and $0.50 \mathrm{~g} / \mathrm{L}$ of $N$. calcicola increased to peak in stage V3 then slightly decreased; whereas, this enzyme in formula of $0.10 \mathrm{~g} / \mathrm{L}$ increased continuously to ending of experiment.

Increased activity of SOD, enzyme engaged in the dismutation of $\mathrm{O}_{2}{ }^{-}$to $\mathrm{H}_{2} \mathrm{O}_{2}$, resulted a strong decrease content of $\mathrm{O}_{2}{ }^{-}$in leaves as soybean in stages of V3 and V5 (Fig. 1b), which support plant cells to protect cellular components from being oxidized by ROS productions. Similar to CAT, SOD regulated ROS generation to avoid oxidative damage and allowed them to play crucial functions in signal transduction [2]. Therefore, we suggested that, the enhanced activity of SOD and CAT observed in "Nam Dan" soybean is one of the important elements in the defense responses to oxidative stress.

\subsubsection{Activity of $A P X$}

Suspension of N.calcicola HN9 in log and death phases both induced expression of APX in "Nam Dan" soybean leaves (Fig. 5). Activity of this enzyme in all experimental formulae differently enhanced from beginning to stage V5. Activity of APX in soybean treated by this cyanobacteria strain in log phase was little higher than in control. For example, the highest 
activity of APX obtained in V5-stage soybean treated by $0.50 \mathrm{~g} / \mathrm{L}$ of N.calcicola HN9 in log phase was $22.83{\text { nkat. } \mathrm{mg}^{-1} \text { protein, having by } 1.24 \text {-fold higher than in control (18.44 nkat.mg }}^{-}$ ${ }^{1}$ protein). Whereas, activity of this enzyme in soybean impacted by the used strain of Cyanobacteria in death phase showed the fast increase to stage V3, then seems to maintain in high level till stage V5 (23.97 - 25.22 nkat.mg ${ }^{-1}$ protein). Although activity of APX in those treated formulae was always higher than others, ANOVA did not confim any correlation between the accumulated activity of APX and the influenced concentration of N.calcicola HN9.

APX is the key enzyme that detoxifies peroxides such as $\mathrm{H}_{2} \mathrm{O}_{2}$ in plant cell using ascorbic acid as a substrate. The importance of APX is not restricted to chloroplasts; it also plays a role in ROS scavenging in cytosol, mitochondria and peroxisomes [17]. Expression of APX often results change in content of ascorbic acid and $\mathrm{H}_{2} \mathrm{O}_{2}$. Additional evidence clearly confirmed this relation in "Nam Dan" soybean as APX maintained high activity during stages V3 and V5, a large amount of ascorbic and $\mathrm{H}_{2} \mathrm{O}_{2}$ reacted, therefore, content of both those substances lowed levels (Fig. 1a and 2a).

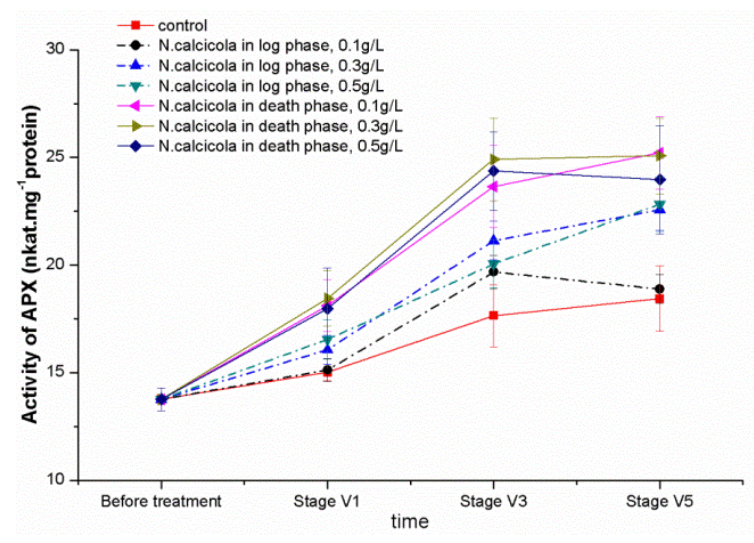

Figure 5. Effect of $N$. calcicola suspension on activity of enzyme ascorbate peroxidase (APX) in "Nam Dan" soybean leaves.

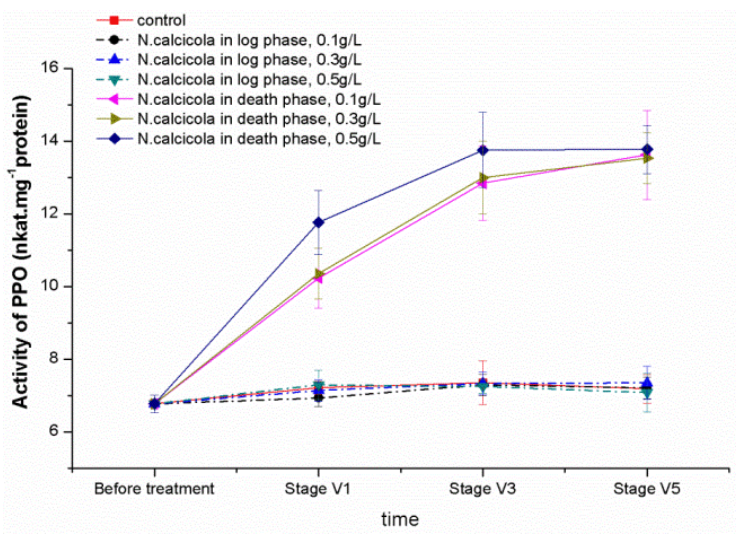

Figure 6. Effect of $N$. calcicola suspension on activity of enzyme polyphenol oxidase (PPO) in "Nam Dan" soybean leaves.

Previously collected data firmly indicate that APX play direct function as protective element against adverse environmental conditions [17]. The diverse effects of knockdown or knockout of different APX isoforms on the plant growth, physiology and antioxidant metabolism indicate that APX may also regulate redox signaling pathways involved in plant development. These results suggested the importance APX in fine tuning the antioxidant metabolism in "Nam Dan" soybean in the vegetative stages.

\subsubsection{Activity of PPO}

$N$. calcicola suspension in log and death phases showed the different effects on expression of enzyme PPO in "Nam Dan" soybean leaves. PPO in leaves treated by strain N.calcicola HN9 in $\log$ phase seems to be stable during the vegetative stages as activity of this enzyme was similar to that in control, which was in minor alteration in level (Fig. 6). Contrary, PPO activity in formulae of N.calcicola HN9 in death phase was induced to increase strongly and continuously from beginning to ending of experiment. The highest activity of PPO obtained in $0.50 \mathrm{~g} / \mathrm{L}$-treated leaves in stage V5 was $13.77 \mathrm{nkat}^{-1} \mathrm{mg}^{-1}$ protein, having by 1.92 -fold higher than in control at the same point of time (7.18 nkat.mg ${ }^{-1}$ protein). 
Plant PPO is a widely distributed and well-studied oxidative enzyme that has broad specific substrates of phenolic compounds. PPO has been extensively studied as part of mechanisms of plant defense against abiotic and biotic stresses [18]. This enzymatic antioxidant was enhanced in "Nam Dan" soybean leaves after treatment by suspension of N.calcicola HN9 in death phase, and caused to reduce content of total phenolics in metabolic reactions in stages V3 and V5 (Fig. $2 \mathrm{~b}$ ). This evidence suggested that, PPO may take part in defense mechanism of "Nam Dan" soybean, however, it was uncertain to confirm what PPO contributes to soybean defense against: biotic factor (strain N.calcicola HN9) or abiotic factor (toxic subtances such as organic acids, ethanol... in death phase suspesion). This important problem should be clarified in the prospective studies.

\section{CONCLUSION}

Strain Nostoc calcicola HN9 in death phase played as an unfavourable factor that caused a burst of ROS productions such as $\mathrm{O}_{2}{ }^{-}$in stage $\mathrm{V} 1$ and $\mathrm{H}_{2} \mathrm{O}_{2}$ in stage $\mathrm{V} 3$, leading to oxidative stress in leaves of "Nam Dan" soybean. Treament by this cyanobacterial strain differently induced to non-enzymatic antioxidants: total phenolics early increased to high content whereas generation of ascorbic acid was inhibited. The enzymatic antioxidants such as SOD, CAT, APX and PPO in N. calcicola HN9-treated plants were differently enhanced during the vegetative stages. High efficiency of the enzymatic antioxidants observed in "Nam Dan" soybean is one important element of soybean defense responses to oxidative stress. Enzymes SOD, CAT, and APX regulated ROS products to avoid oxidative damage and may allow them to play crucial functions in signal transduction leading to increase soybean tolerance. Only the defensive role of PPO should be clarified in the prospective studies.

Contrary, N. calcicola HN9 in log phase slightly raised generation of ascorbic acid and induced activity of SOD and APX; the effective level was much lower in comparing to those resulted by $N$. calcicola HN9 in death phase. Lack of convinced evidences discribed how this strain in log phase influenced (stimulated or inhibited) on biosynthesis of total phenolics and expression of CAT and PPO.

Acknowledgement. This research is funded by Vietnam National Foundation for Science and Technology Development (NAFOSTED) under grant number: 106-NN.03-2014.22.

\section{REFERENCES}

1. Bhattacharjee S. - Reactive oxygen species and oxidative burst: Roles in stress, senescence and signal transduction in plants, Curr. Sci. 89 (2005) 1113-1121.

2. Mai V C., Bednarski W., Borowiak-Sobkowiak B., Wilkaniec B., Samardakiewicz S., and Morkunas I. - Oxidative stress in pea seedlings leaves in response to Acyrthosiphon pisum infestation, Phytochemistry 93 (2013) 49-62.

3. Maffei M. E., Mith $\square$ fer A., and Boland W. - Insects feeding on plants: Rapid signals and responses preceding the induction of phytochemical release, Phytochemistry 68 (2007) 2946-2959.

4. Ahmad P., Sarwat M., and Sharma S. - Reactive oxygen species, antioxidants and signaling in plants, J. Plant Biol. 51 (2008) 167-173. 
5. Zhu-Salzman K., Salmon R. A., Ahn J. E., and Koiwa H. - Transcriptional regulation of sorghum defense determinants against a phloem-feeding aphid, Plant Physiol. 134 (2004) 420-431.

6. Molina G. E., Belarbi E. H., Acien F. F. G., Robles M. A., and Chisti Y. - Recovery of microalgal biomass and metabolites: process options and economics, Biotechnol. Adv. 20 (2003) 491-515.

7. Becana M., Aparicio-Tejo P., Irigoyen J.J., and Sanchez-Diaz M. - Some enzymes of hydrogen peroxide metabolism in leaves and root nodules of Medicago sativa, Plant Physiol. 82 (1986) 1169-1171.

8. Doke N. - Involvement of superoxide anion generation in the hypersensitive response of potato tuber tissues to infection with an incompatible race of Phytophthora infestans and to the hyphal wall components, Physiol. Plant Pathol. 23 (1983) 345-357.

9. Kampfenkel K., Van Montagu M., and Inze D. - Extraction and determination of ascorbate and dehydroascorbate from plant tissue, Anal. Biochem. 225 (1995) 165-167.

10. Mechikova G. Y., Stepanova T. A., and Zaguzova E. V. - Quantitative determination of total phenols in strawberry leaves, Pharmaceutical Chemistry J. 41 (2007) 97-100.

11. Scebba F., Sebastiani L., and Vitagliano C. - Protective enzymes against activated oxygen species in wheat (Triticum aestivum L.) seedlings: Responses to cold acclimation, J. Plant Physiol. 155 (1999) 762-768.

12. Chen Y., Cao X. D., Lu Y., and Wang X. P. - Effects of rare earth ions and their EDTA complexes on antioxidant enzymes of fish liver, Bull. Environ. Contam. Toxicol. 65 (2000) 357-365.

13. Cao X., Ma L. Q., and Tu C. - Antioxidative responses to arsenic in the arsenichyperaccumulator chinese barke fern (Pteris vittata L.), Environ. Poll. 128 (2004) 317325.

14. González E. M., de Ancos B., and Cano M. P. - Partial characterization of polyphenol oxidase activity in raspberry fruits. J. Agric. Food Chem. 47 (1999) 4068-4072.

15. Bradford M. M. - A rapid and sensitive method for the antification of microgram quantities of protein utilizing the principle of protein-dye binding, Anal. Biochem. 72 (1976) 248-254.

16. Mai V. C., Nguyen D. D., and Nguyen D. S . - Hypersensitive response in soybean roots to lead, Journal of Science and Development (Vietnam National University of Agriculture) 12(7) (2014) 1023-1028 (in Vietnamese)

17. Shigeoka S., Ishikawa T., Tamoi M., Miyagawa Y., Takeda T., Yabuta Y., and Yoshimura K. - Regulation and function of ascorbate peroxidase isoenzymes, J. Exp. Bot. 53 (2002) 1305-1319

18. Constabel C.P. and Barbehenn R. - Defensive roles of polyphenol oxidase in plants, in: Schaller A. (ed.), Induced plant resistance to herbivory, Springer Science+ Business Media B.V. (2008) 253-269. 


\title{
TÓM TẮT
}

\section{ẢNH HƯỞNG CỦA VI KHUẨN LAM Nostoc calcicola ĐỐI VỚI HỆ THỐNG CHỐNG ÔXY HÓA CỦA GIỐNG ĐẬU TƯƠNG NAM ĐÀN}

\author{
Mai Văn Chung ${ }^{1, *}$, Mai Thị Thanh Huyền ${ }^{2}$, Đinh Thị Trường Giang ${ }^{2}$ \\ ${ }^{1}$ Khoa Sinh học, Truờng đại học Vinh, 182 Lê Duẩn, thành phố Vinh, tỉnh Nghệ An \\ ${ }^{2}$ Khoa Hóa học, Truờng đại học Vinh, 182 Lê Duẩn, thành phố Vinh, tỉnh Nghệ An \\ *Email: chungmv@vinhuni.edu.vn
}

Chủng vi khuẩn lam (VKL) Nostoc calcicola HN9 ở pha suy vong và pha lũy thừa đã có ảnh hưởng khác nhau đối với một số thành phần của hệ thống chống ôxy hóa ở cây đậu tương Nam Đàn [Glycine max (L.) Merr.] trong các giai đoạn sinh trưởng phát triển sinh dưỡng.

Dịch $N$. calcicola $\mathrm{HN} 9$ ở pha suy vong đã gây stress “ôxy hóa” ở lá đậu tương với sự tổng hợp mạnh mẽ gốc tự do superoxide $\left(\mathrm{O}_{2}^{\circ}{ }^{\circ}\right)$ trong giai đoạn $\mathrm{V} 1$ và hydrogen peroxide $\left(\mathrm{H}_{2} \mathrm{O}_{2}\right)$ ở giai đoạn V3. Sau khi có tác động của VKL, hàm lượng phenol tổng số tăng nhanh còn sinh tổng hợp axit ascorbic bị ức chế; các enzyme như superoxide dismutase (SOD), catalase (CAT) và ascorbate peroxidase (APX) được cảm ứng tăng cường độ hoạt động. Sự gia tăng này góp phần kiểm soát quá trình tổng hợp, chuyển hóa $\mathrm{O}_{2}$ " và $\mathrm{H}_{2} \mathrm{O}_{2}$, giảm tác hại của stress "ôxy hóa".

Trái lại, dịch VKL ở pha lũy thừa có tác dụng tốt đối với sinh tổng hợp axit ascorbic trong giai đoạn V1, thúc đẩy gia tăng hoạt độ các enzyme SOD và APX nhưng ở mức độ thấp hơn so với tác động của dịch VKL ở pha suy vong, đồng thời ảnh hưởng chưa rõ ràng đến phenol tổng số, CAT và PPO ở cây đậu tương Nam Đàn.

Tù khóa: đậu tương Nam Đàn, vi khuẩn lam, Nostoc calcicola HN9, chất chống ôxy hóa, enzyme chống ôxy hóa. 